\title{
Solid State Fermentation for Cultural Conditions Optimization and Production of $\alpha$-Amylase from Bacillus licheniformis ATCC 12759
}

\author{
Bacillus licheniformis ATCC 12759'dan $\alpha$-Amilazın Üretimi ve \\ Kültür Koşullarının Optimizasyonu için Katı Faz Fermentasyonu
}

\author{
Research Article \\ Nurullah Akcan ${ }^{1 *}$ and Besi Serin ${ }^{2}$ \\ 'Health School, Siirt University, Siirt, Turkey. \\ 2Dicle University, Faculty of Science, Department of Biology, Diyarbakır, Turkey.
}

\section{A B S TR AC T}

\begin{abstract}
The aim of this paper is to study influence of the certain production parameters of $\alpha$-amylase by Bacillus licheniformis ATCC 12759. Various agroresidues as substrate were studied for enzyme production. The highest enzyme production was expressed with rice bran as units per mass of dry substrate $(1399.8 \pm 6.6 \mathrm{U} / \mathrm{mg})$. Optimization parameters of $\alpha$-amylase production were carried out with solid state fermentation (SSF). Solid waste from rice bran used as the basic nutrient source. Supplementation with carbon and metal salt sources decrased the enzyme production. Certain fermentation parameters involving incubation time, incubation temperature, inoculum level, moisture level, extraction medium, initial $\mathrm{pH}$ and medim volume were studied separately. Maximal amount of $\alpha$-amylase production $(2094.9 \pm 53.1 \mathrm{U} / \mathrm{mg}$ ) was obtained inoculum level $30 \%$, moisture level $20 \%$, initial $\mathrm{pH} 6.5$ at $37^{\circ} \mathrm{C}$ for $48 \mathrm{~h}$ with supplementation of ammonium cloride.
\end{abstract}

\section{Key Words}

Bacillus licheniformis ATCC 12759, rice bran, $\alpha$-amylase, solid state fermentation, optimization, production.

\section{öz}

u çalışmanın amacı Bacillus licheniformis ATCC 12759'dan $\alpha$-amilazın belirli üretim parametrelerinin etkisini incelemektir. Enzim üretimi için substrat olarak çeşitli tarımsal atıklar çalışılmıştır. En yüksek enzim üretimi kütle başına $(1399.8 \pm 6.6 \mathrm{U} / \mathrm{mg})$ pirinç kabuğu ile ifade edildi. $\alpha$-Amilaz üretiminin optimizasyon parametreleri katı faz fermantasyonu (KSF) ile gerçekleştirildi. Katı atık olarak pirinç kabuğu temel besin kaynağı olarak kulıanıldı. İnkübasyon zamanı, inkübasyon sıcaklığı, inokülum oranı, nem oranı, özütleme ortamı, başlangıç pH'sı ve ortam hacmini içeren belirli fermantasyon parametreleri ayrı ayrı çalışıldı. $\alpha$-Amilaz üretiminin en yüksek miktarı (2094.9 $\pm 53.1 \mathrm{U} / \mathrm{mg}$ ) 48. saatte $37^{\circ} \mathrm{C}$ 'de başlangıç pH $6.5 \% 20$ nem oranı ve \%30 aşılama oranı ile amonyum klorürün eklenmesi ile elde edilmiştir.

\section{Anahtar Kelimeler}

Bacillus licheniformis ATCC 12759, pirinç kabuğu, $\alpha$-amilaz, katı faz fermantasyonu, optimizasyon, üretim.

Article History: Received: Apr 07, 2017; Revised: May 21, 2017; Accepted: Sep 12, 2017; Available Online: Dec 25, 2017. DOI: 10.15671/HJBC.2018.202 


\section{INTRODUCTION}

mylase $(\alpha-1,4$-glucan 4 -glucanohydrolase, EC

3.2.1.1) is an enzyme that degrades starch, first to oligosaccharides and then in turn to maltose and glucose, by hydrolyzing $\alpha-1,4$-glucan bonds [1]. Amylases are employed in industries for different purposes; glucose and maltose-forming $\alpha$-amylases in alcohol fermentation and sugar syrup formulation, and malto-oligosaccharide-forming $\alpha$-amylases in food processing $[2,3]$. Amylases also play a significant role in starch, detergent, beverage and textile industries and its commercial production from microorganisms represent $25-33 \%$ of the world enzyme market $[4,5]$. $\alpha$-Amylases are ubiquitous enzymes produced by plants, animals and microbes. In spite of the wide distribution of amylases, microbial sources, namely fungal and bacterial amylases, are used for the industrial production due to advantages such as cost effectiveness, consistency, less time and space required for production and ease of process modification and optimization $[6,7]$.

Commercial $\alpha$-amylase is usually produced by $\mathrm{SmF}$ but the cost of enzyme production in submerged fermentation (SmF) is high. The contents of synthetic media are very expensive and these contents might be replaced with more economically available agricultural by-products for the reduction of cost of the medium [8]. The use of agricultural wastes makes solid-state fermentation (SSF) an attractive alternative method $[9,10]$. SSF is defined as the cultivation of microorganisms on moist solid support, either on inert carriers or insoluble substrates that can, in addition be used as carbon and energy source. The aim of SSF is to bring the cultivated microorganisms into tight contact with the insoluble substrate and thus to achieve the highest substrate concentration during fermentation [11]. Bacterial systems are now being increasingly investigated for the production of enzymes and metabolites by solid-state fermentation [12].

SSF has numerous advantages, including high volumetric productivity, relatively higher concentration of the products, less effluent generation, and requirement for simple fermentation equipments than SmF $[1,13,14]$. The major factors that affect mic robial synthesis of enzymes in a SSF system include selection of a suitable substrate and microorganism, particle size of the substrate, inoculum concentration and moisture level of the substrate $[10,15]$.

Development of an economical production medium requires the selection of a carbon, nitrogen, phosphorus, sulfur, potassium and trace element source as well as energy source that will support not only good microbial growth but also maximize product yield, reduce synthesis of compounds closely related to the product and enhance product recovery [16]. The objective of the present study was to screen a variety of agro-industrial waste residues as substrates for $\alpha$-amylase production by Bacillus licheniformis ATCC 12759 in SSF and optimization of fermentation conditions with respect to moisture content and extraction medium of the best fermentable material, incubation time, incubation temperature, initial $\mathrm{pH}$, volume of fermentation medium, supplementation of carbon, nitrogen and metal salt sources for $\alpha$-amylase production in SSF.

\section{MATERIALS and METHODS}

\section{Chemicals}

All reagents used in this study were purchased from Sigma (USA).

\section{Microorganism and Growth Medium}

$\alpha$-Amylase producing $B$. licheniformis ATCC 12759 which was purchased from MicroBioLogics, Inc. was used as biological material. B. licheniformis ATCC 12759 was grown on nutrient agar at $37^{\circ} \mathrm{C}$ for $24 \mathrm{~h}$ for inoculum preparation. A loopful of the growth was transferred to Luria broth (LB) liquid medium (1\% yeast extract, $0.5 \%$ peptone, $0.5 \%$ $\mathrm{NaCl},(\mathrm{w} / \mathrm{v}), \mathrm{pH} 7.0)$.

\section{Substrate}

Wheat bran (WB), rice bran (RB), cotton stalk (CS), crushed maize (CM), millet cereal (MC) were obtained in Diyarbakır, Turkey. The substrates were ground into coarse powder with a blender and used. The rice bran which found as best substrate was used to be solid substrate. This is cheap and readily available in the local market, Diyarbakır, Turkey.

\section{Solid State Fermentation}

In an attempt to choose a potential substrate for SSF which supports $\alpha$-amylase production, vario- 
us agro residues like wheat bran (WB), rice bran $(\mathrm{RB})$, cotton stalk (CS), crushed maize (CM), millet cereal (MC) were screened individually. SSF was carried out by taking $3 \mathrm{~g}$ of dry substrate in a 100 $\mathrm{mL}$ Erlenmeyer flask to which distilled water was added to adjust the required moisture level. The contents of the flasks were mixed and autoclaved at $121^{\circ} \mathrm{C}$ for $15 \mathrm{~min}$. Flasks with inoculated with 3.0 $\mathrm{ml}$ of spore suspension $\left(2.10^{7} \mathrm{CFU} / \mathrm{mL}\right)$ were shaken at $150 \mathrm{rpm}$ at $37^{\circ} \mathrm{C}$ for $144 \mathrm{~h}$. The contents of the flasks were harvested and assayed every $24 \mathrm{~h}$.

\section{Enzyme Extraction}

The enzyme from the fermented bacterial bran was extracted twice with tap water. The slurry was squeezed through damp cheesecloth. Extracts were pooled and centrifuged at $4^{\circ} \mathrm{C}$ for 15 min at $10.000 \mathrm{rpm}$ to separate small particles of different substrates, cells and spores. The yellow, clear supernatant was used in enzyme assays.

\section{Enzyme Assay}

$\alpha$-Amylase activity was determined by the procedure of Bernfeld using soluble starch as a substrate [17]. The reaction mixture containing $200 \mu \mathrm{l}$ of $1 \%$ substrate $(\mathrm{w} / \mathrm{v})$ in $0.1 \mathrm{M}$ phosphate buffer $(\mathrm{pH}$ 7.0) and $150 \mu \mathrm{l}$ of enzyme solution was incubated for $30 \mathrm{~min}$ at $37^{\circ} \mathrm{C}$. The reaction was stopped by adding $400 \mu \mathrm{l}$ of 3,5-dinitrosalicylic acid solution followed by heating in a boiling water bath for 5 min and cooling at room temperature and then $8 \mathrm{ml}$ of deionized water was added. Absorbance of each solution containing the brown reduction product was measured at $489 \mathrm{~nm}$ in a UV-Visible spectrophotometer.

One unit $(U)$ of $\alpha$-amylase activity was defined as the amount of enzyme that releases $1 \mu \mathrm{mol}$ of reducing sugar as maltose per minute, under assay conditions and expressed as $\mathrm{U} / \mathrm{mg}$ of dry substrate.

All the experiments are independent of each other. Results are represented as mean \pm S.D. of at least three experiments.

\section{Protein Determination}

The protein amount was determined by Lowry method by using bovine serum albumine (BSA) as standart [18].

\section{Effect of Process Parameters on $\alpha$-Amylase Production in SSF}

Various process parameters influencing enzyme production during SSF were optimized. The strategy was to optimize each parameter independently of the others and subsequently optimal conditions were employed in all experiments. The rice bran was employed for further optimization of process parameters, namely incubation time (24-96 h), incubation temperature $(30,37,40$, 45 and $50{ }^{\circ} \mathrm{C}$ ), inoculum size (10-80\%), moisture level $(20,30,40,50,60$ and $80 \%)$, extraction medium (distilled water, tap water, $50 \mathrm{mM}$ $\mathrm{NaCl}, 0.1 \mathrm{M}$ phosphate buffer $(\mathrm{pH} 7.0), 1 \%$ solution of various detergents like Tween 40, CHAPS (3-[(3-Cholamido-propyl)-dimethylammonio]propane- sulfonate), sodium dodesil sulfate (SDS) and Triton $\mathrm{X}-100)$, initial $\mathrm{pH}$ of the medium $(\mathrm{pH}$ 5.0-9.0) and volume of fermentation medium $(100,250,500$ and $1000 \mathrm{ml}$ erlenmeyer flaks) were optimized. To study the efficacy of various inducers, the medium was supplemented independently with $1 \%$ mannose, xylose, lactose, sucrose, fructose, galactose, glucose, and arabinose. While nutrient supplementation such as inorganic nitrogen sources 1\% (by mass) (ammonium nitrate, sodium nitrate, ammonium chloride and ammonium sulphate), organic nitrogen sources (peptone, tryptone, yeast extract, beef extract, urea, and casein), and added metal salts $0.1 \%$ (by mass) $\mathrm{FeSO}_{4} \cdot 7 \mathrm{H}_{2} \mathrm{O}, \mathrm{MgSO}_{4} \cdot 7 \mathrm{H}_{2} \mathrm{O}, \mathrm{CuSO}_{4} \cdot 5 \mathrm{H}_{2} \mathrm{O}$, $\mathrm{ZnSO}_{4} \cdot 7 \mathrm{H}_{2} \mathrm{O}$ and $\mathrm{CaCl}_{2}$ were optimised. For each experimental variable all other parameters were kept at their optimal level.

\section{RESULTS and DISCUSSION}

It has been well documented that Bacillus species served as the most important sources of $\alpha$-amylase[5,8,10,11]. In SSF, the selection of a suitable solid substrate for a fermentation process is a critical factor and thus involves the screening of a number of agro-industrial materials for microbial growth and product formation [19]. In this study in order to reduce the cost of $\alpha$-amylase production, agro-industrial residues or cheap materials were choosen as culture media. As it is shown in Table 1, A high titer of $\alpha$-amylase production $(1399.8 \pm 6.6 \mathrm{U} / \mathrm{mg})$ was obtained in a medium containing rice bran (RB) alone as the substrate. 
Table 1. Effect of different agro-industrial wastes on B. licheniformis ATCC $12759 \alpha$-amylase production by solid state fermentation.

\begin{tabular}{lccccc}
\hline & \multicolumn{5}{c}{ Substrates } \\
\cline { 2 - 6 } Hour & Cotton stalk (CS) & Rice bran (RB) & Millet cereal (MC) & $\begin{array}{c}\text { Wheat bran } \\
\text { (WB) }\end{array}$ & Crussed maize (CM) \\
\cline { 2 - 6 } & \multicolumn{5}{c}{ Enzyme Production (U/mg) } \\
\hline 24 & $448.7 \pm 30.2$ & $1127.8 \pm 15.0$ & $781,3 \pm 72.3$ & $639.8 \pm 7.5$ & $428.2 \pm 34.2$ \\
\hline 48 & $519.4 \pm 5.8$ & $1399.8 \pm 6.6$ & $786.6 \pm 3.1$ & $202.9 \pm 1.6$ & $382.0 \pm 18.1$ \\
\hline 96 & $527.5 \pm 3.3$ & $1225.6 \pm 36.6$ & $455.4 \pm 15.9$ & $196.7 \pm 4.7$ & $282.8 \pm 21.3$ \\
\hline
\end{tabular}

Recently, SSF of rice bran was developed to replace wheat bran in the tropics [20]. Wheat bran is reported to give higher enzyme yield compared to rice bran and other agro-wastes [9], while comparable $\alpha$-amylase production has been reported using rice components versus wheat bran as solid substrate for fermentation [13,21-23]. However, using this substrate also solves pollution problems. Due to the superior potential of RB in inducing the $\alpha$-amylase production by $B$. licheniformis ATCC 12759 in SSF, this substrate was selected for subsequent experiments (optimization of process parameters)

The incubation time was governed by the characteristics of the culture, based on the growth rate and the enzyme production pattern [24]. Maximum enzyme production $(1466.7 \pm 2.1 \mathrm{U} / \mathrm{mg})$ was observed after $48 \mathrm{~h}$, which decreased with further incubation (Figure 1). The reason for this might have been due to the denaturation of the enzyme caused by the interaction with other components in the medium [25].

Temperature is one of the important factors, which strongly affect the SSF process. It plays a significant role in development of the biological process as it influences protein denaturation, enzyme inhibition and cell growth [26]. It has been reported that during microbial cultivation in SSF, the temperature of the fermenting bed increased, which exerted harmful effects on the microbial activity $[27,28]$. Investigation of the effect of temperature on enzyme production during fermentation showed that the optimum temperature for maximum yield of $\alpha$-amylase was $37^{\circ} \mathrm{C}$ for rice bran (Figure 2). Maximum production at lower temperatures may be advantageous as it can reduce the rate of evaporation during incubation [22]. Previously similar results were reported for

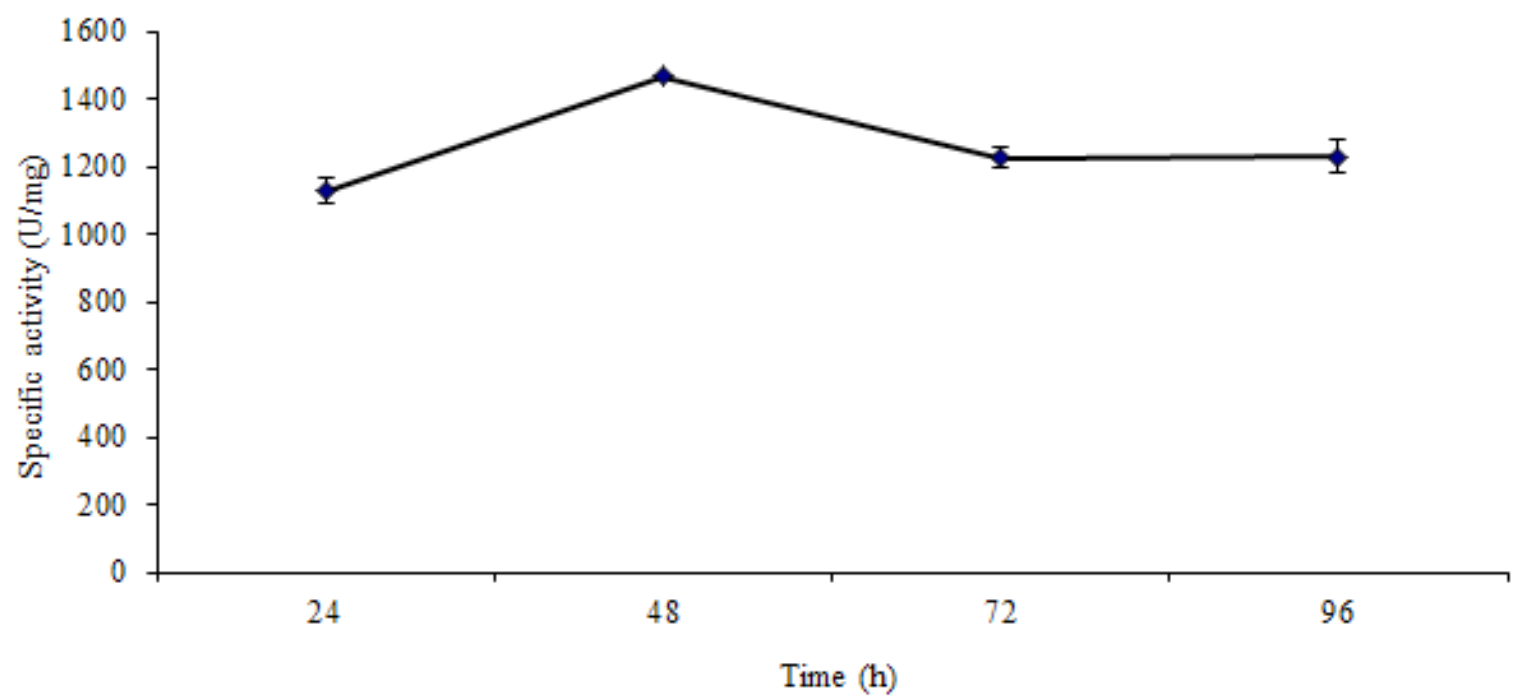

Figure 1. Effect of incubation time on the production of $\alpha$-amylase by $B$. licheniformis ATCC 12759 . Inoculum size $30 \%$ (by volume per mass), Moisture level $20 \%$, Extraction medium with tap water, Initial pH 6.5 , Incubation temperature $37^{\circ} \mathrm{C}$. 


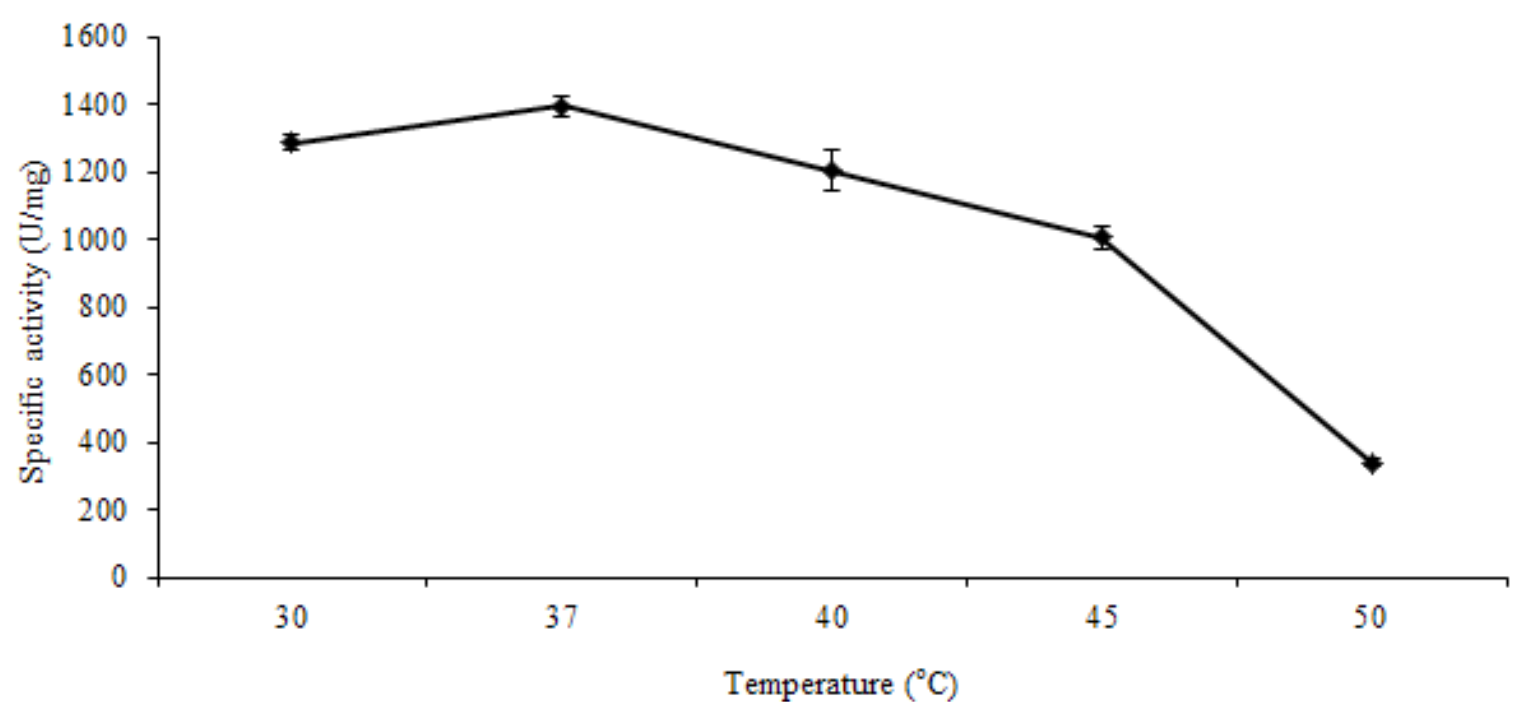

Figure 2. Effect of incubation temperature on the production of $\alpha$-amylase by $B$. licheniformis ATCC 12759. Inoculum size $30 \%$ (by volume per mass), Moisture content $20 \%$, Extraction medium with tap water, Initial pH 6.5, Incubation time 48.

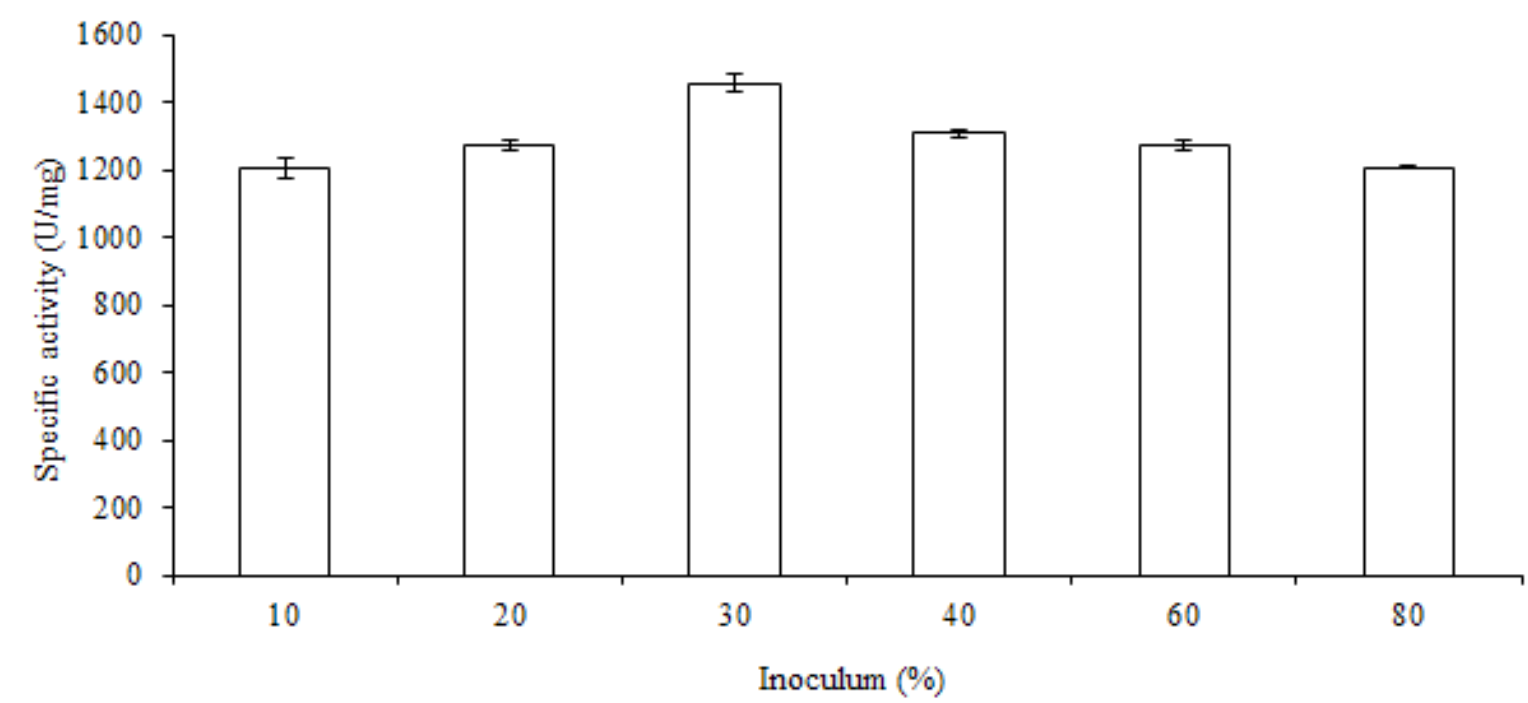

Figure 3. Effect of inoculum size on the production of $\alpha$-amylase by B. licheniformis ATCC 12759. Moisture level 20\%, Initial pH 6.5, Extraction medium with tap water, Incubation temperature $37^{\circ} \mathrm{C}$, Incubation time 48 .

production of $\alpha$-amylase $[10,23,29,30]$. It has also been reported that the metabolic heat generated during microbial cultivation in SSF exerts harmful effects on the microbial activity and thus the initial set temperature is vital [31].

There is a great influence of inoculum's concentration in enzyme production and therefore, this parameter should be given a proper consideration for optimum level of $\alpha$-amylase production [32]. Various inoculum levels were tried to determine their effect on enzyme production. The higher enzyme

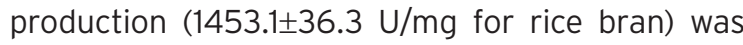

obtained at $30 \%$ inoculum level, as compared to lower or higher inoculum levels (Figure 3 ). The results from this study indicate that $30 \%$ inoculum size was optimal, balancing enzyme and biomass production.

Moisture content of the substrate is one of the critical factors influencing the outcome of SSF, and is governed by the water-holding-capacity of the substrate, the type of end-product, and the requirement of the microorganism. The inter particle mass transfer within the solid phase to the growing microorganism depends on the substrate characteristics and the moisture content [33] The moisture content 


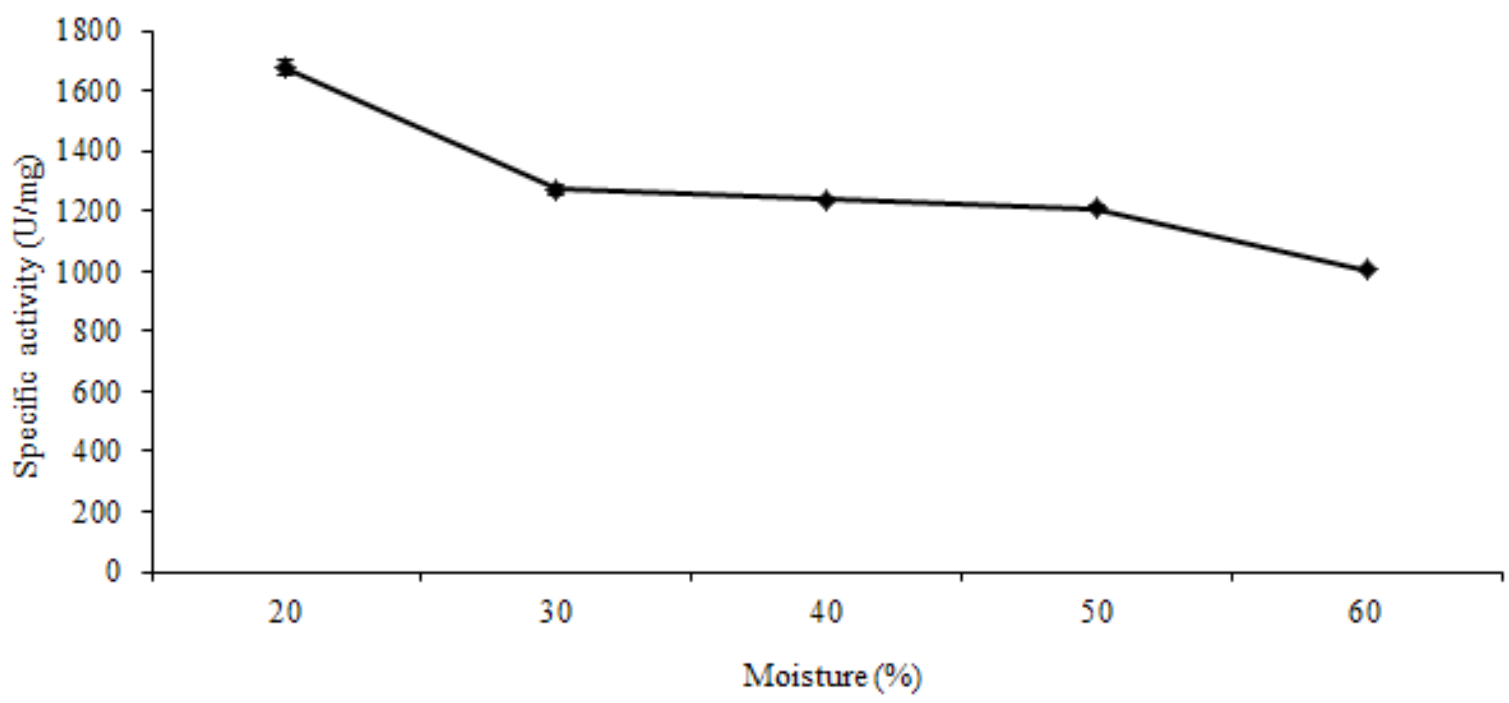

Figure 4. Effect of moisture level on the production of $\alpha$-amylase by $B$. licheniformis ATCC 12759 . Inoculum size $30 \%$ (by volume per mass), Extraction medium with tap water, Initial pH 6.5, Incubation temperature $37^{\circ} \mathrm{C}$, Incubation time 48 .

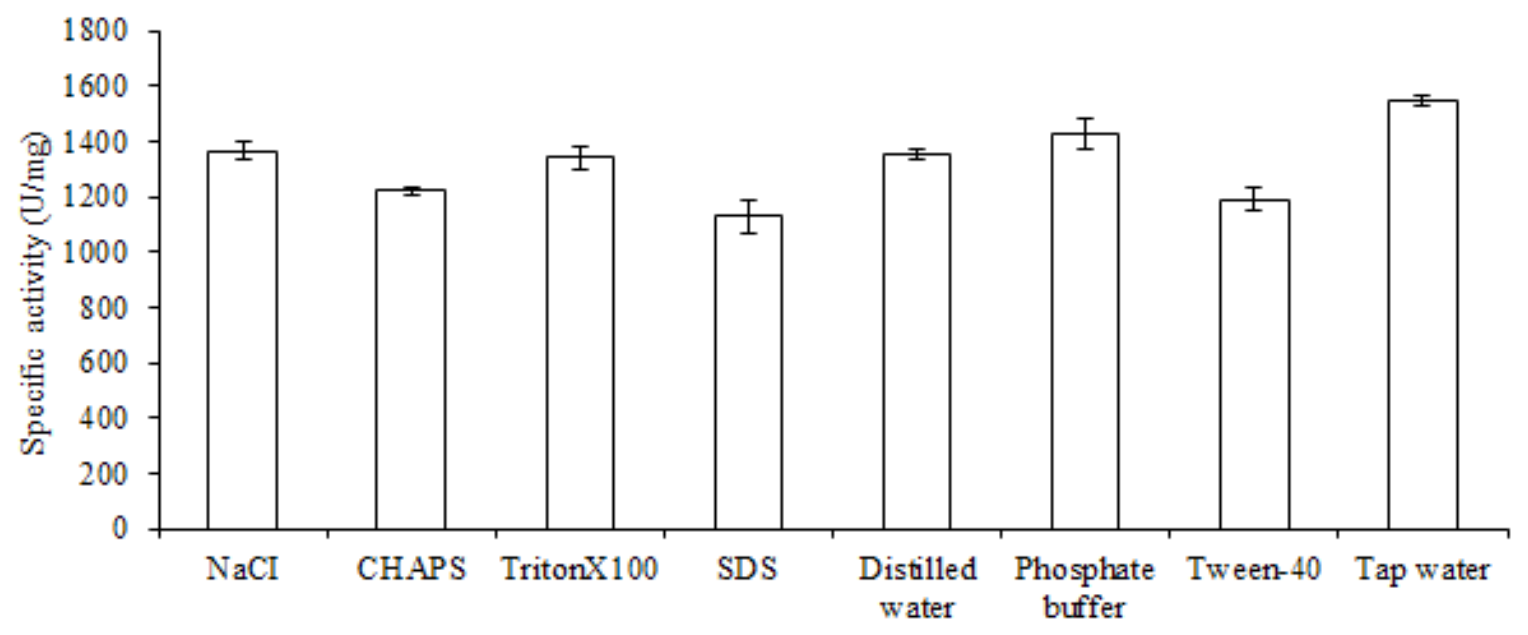

Extraction medium $(10 \mathrm{ml})$

Figure 5. Effect of extraction medium on the production of $\alpha$-amylase by $B$. licheniformis ATCC 12759 . Inoculum size $30 \%$ (by volume per mass), Moisture content $20 \%$, Initial pH 6.5, Incubation temperature $37^{\circ} \mathrm{C}$, Incubation time 48.

of the medium changes during fermentation as a result of evaporation and metabolic activities and thus optimum moisture level of the substrate is therefore most important [13]. In the present study, high enzyme production was obtained when the moisture level was maintained as $20 \%$ in comparison with that at other moisture levels $(30,40,50$ and $60 \%)$ (Figure 4). Increase in moisture level is believed to reduce the porosity of the solid substrate, thus limiting oxygen transfer [25].

To obtain the enzyme extraction from fermented biomass is important. The medium used for the extraction of crude enzyme from the fermented matter was found to have a profound effect on the enzyme yield [31]. The effect of different solvents on enzyme extraction is presented in Figure 5. Maximum enzyme production $(1547.3 \pm 17.0 \mathrm{U} / \mathrm{mg})$ was obtained with tap water, which supported amylase production.

$\mathrm{pH}$ is among the other most important factors for any fermentation process and is dependent upon the type of the moistening agent used in the medium. Each microorganism possesses a $\mathrm{pH}$ range for its growth and activity with a optimum 


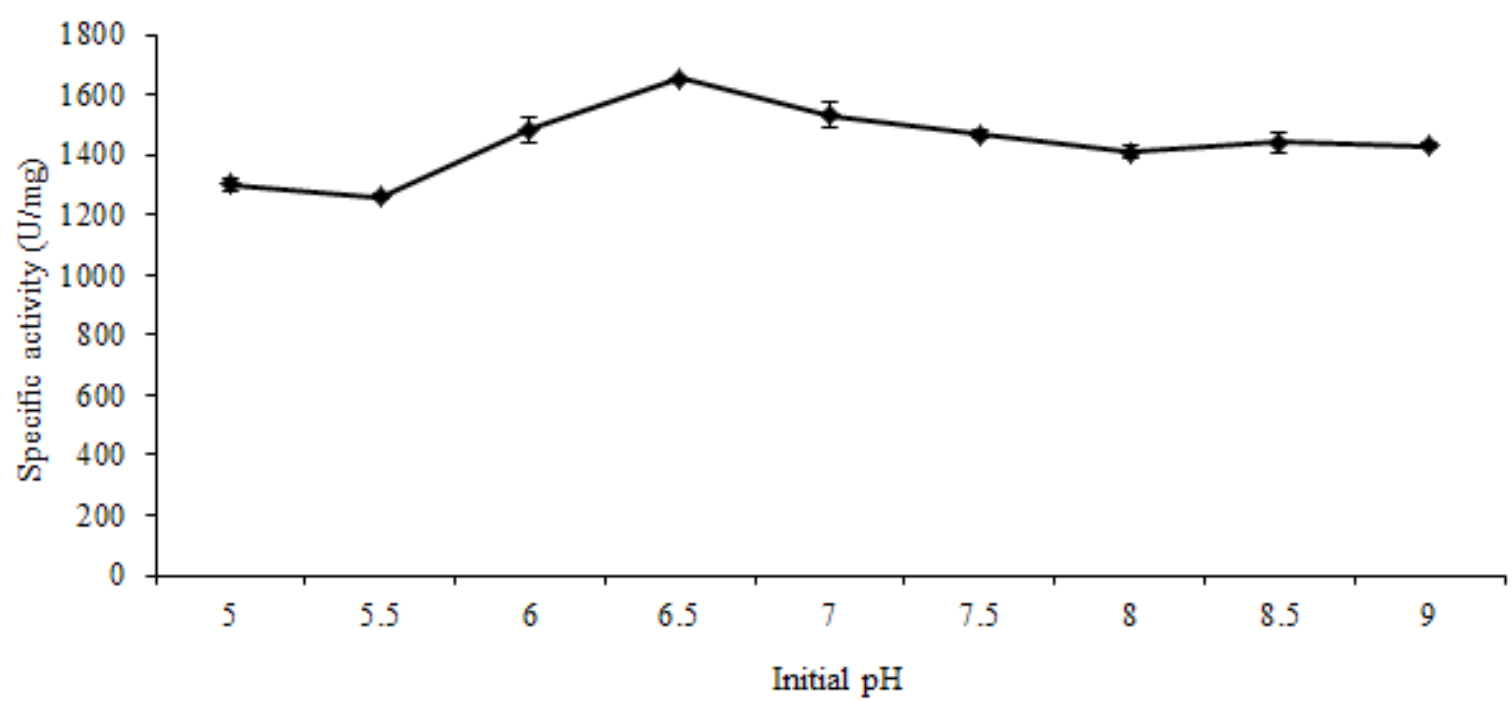

Figure 6. Effect of initial pH on the production of $\alpha$-amylase by $B$. licheniformis ATCC 12759. Inoculum size $30 \%$ (by volume per mass), Moisture content \%20, Extraction medium with tap water, Incubation temperature $37^{\circ} \mathrm{C}$, Incubation time 48 .

value in between the range [23]. The $\mathrm{pH}$ change observed during the growth of the organism also affects product stability in the medium. Most of the Bacillus strains used commercially for the production of bacterial $\alpha$-amylases by SmF have an optimum $\mathrm{pH}$ between 6.0 and 7.0 for growth and enzyme production. This is also true of strains used in the production of the enzyme by SSF [24]. In the present study, the initial pH of the fermentation medium was founded to 6.5 (Figure 6). An attempt to overcome the problem of $\mathrm{pH}$ variability during the SSF process is obtained by the substrate formulation considering the buffering capacity of the different components employed or by the use of buffer formulation with components that have no deleterious influence on the biological activity $[23,25]$. Generally, agro industrial wastes possess unique buffering action and have advantages for enzyme production. The subsequent experiments, the initial $\mathrm{pH}$ of the fermentation medium was adjusted to 6.5.

Most of the laboratory studies on the production of enzymes using the SSF technique have employed Erlenmeyer flasks and trays [22-24,34-36]. To improve for a large-scale SSF, $\alpha$-amylase production was investigated in four different fermentation medium sizes (100, 250, 500 and $1000 \mathrm{~mL}$ erlenmayer flasks). When solid state fermentation with $B$. licheniformis ATCC 12759 was carried out in erlenmayer flasks of various sizes with corresponding increase in with different quantities of rice bran moistened with appropriate amounts of tap water, maximum enzyme production $(1642.6 \pm 52.7 \mathrm{U} / \mathrm{mg}$ ) observed in $500 \mathrm{ml}$ erlenmayer flasks containing $10 \mathrm{~g}$ of rice bran comparision with control (containing $2 \mathrm{~g}$ of rice bran) (Figure 7). This result suggested that the possibility of large scale production of Bacillus licheniformis ATCC 12759 under SSF.

The supplementation of rice bran with the different carbon sources; mannose, xylose, lactose, sucrose, fructose, galactose, glucose, and arabinose at $1 \%(\mathrm{w} / \mathrm{v})$ concentration on the production of $\alpha$-amylase by $B$. licheniformis ATCC 12759 was investigated in order to obtain a suitable medium for industrial enzyme production. In our studies, as shown in Table 2 in comparison with the control $(1800.6 \pm 18.2 \mathrm{U} / \mathrm{mg})$, there was no significant increase in enzyme yield in the case of the supplementation of carbon sources. All carbon sources resulted in suppression of $\alpha$-amylase production by $B$. licheniformis ATCC 12759 which might be due to catabolic repression of $\alpha$-amylase synthesis [37]. In a sharp contrast to this observation, many of the authors have reported either absence or a minor catabolic repression of $\alpha$-amylase synthesis by microbes in SSF in presence of glucose $[23,28]$. Therefore, it might be reasonable to assume that the effect of glucose on induction of $\alpha$-amylase synthesis is dependent on the microbial species [32]. 


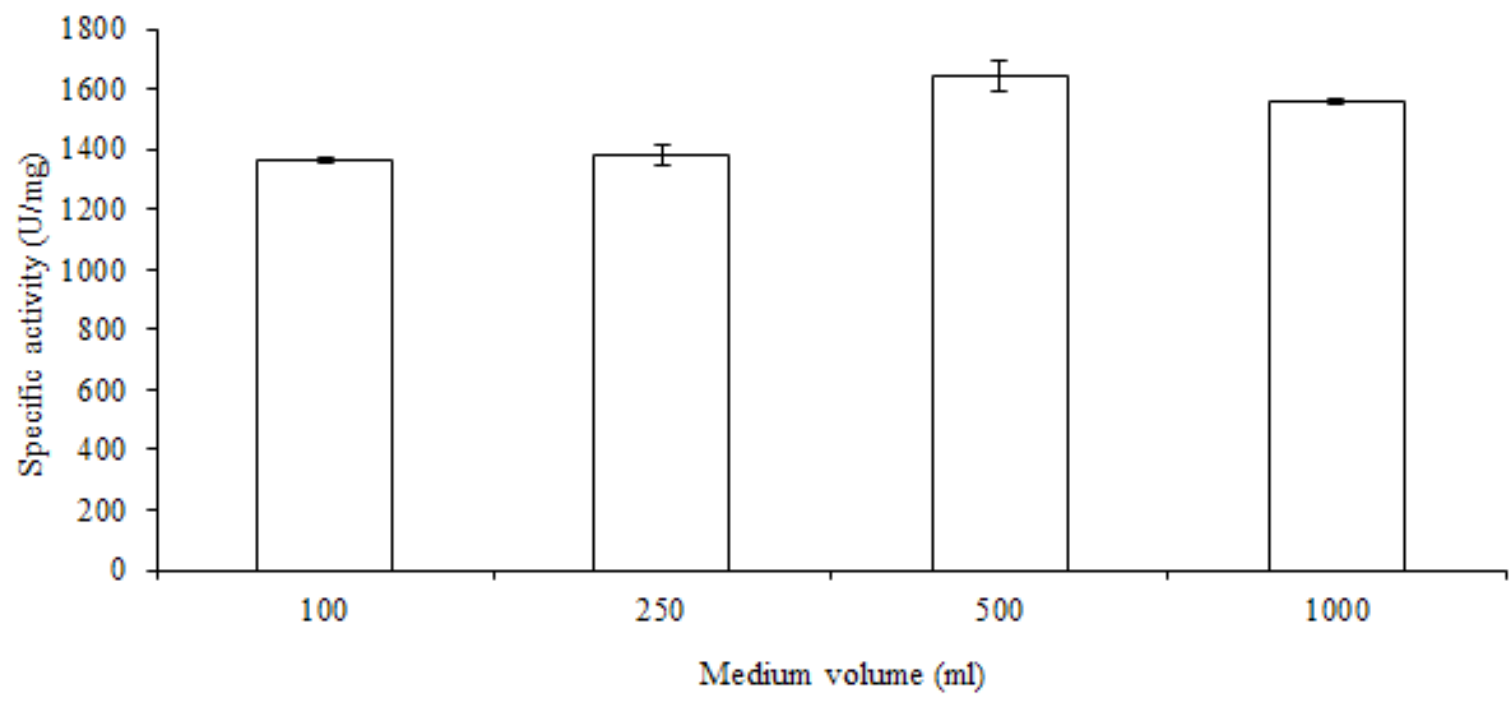

Figure 7. Effect of medium volume on the production of $\alpha$-amylase by $B$. licheniformis ATCC 12759 . Inoculum size $30 \%$ (by volume per mass), Moisture content $20 \%$, Extraction medium with tap water, Initial pH 6.5, Incubation temperature $37^{\circ} \mathrm{C}$, Incubation time 48 .

The composition of rice bran is approximately $10 \%$ protein, $10 \%$ moisture, $20 \%$ crude fiber, $15 \%$ crude fat and $45 \%$ carbohydrates [38]. Maximum $\alpha$-amylase production was obtained with rice bran as the substrate. It may not provide all the nutrients needed by the organism for maximum enzyme production or some of the vital nutrients necessary for growth and enzyme formation may be present at sub-optimal level. Hence, the exogenous addition of various nutrients to the solid medium improves the growth of organism and the product yield $[39,40]$. Addition of organic nitrogen sources such as casein, peptone, tryptone, yeast extract, beef extract, urea

Table 2. Effect of carbon sources on the production of $\alpha$-amylase by $B$. licheniformis ATCC 12759. Inoculum size $30 \%$ (by volume per mass), volume of medium $100 \mathrm{ml}$ Extraction medium with tap water, Initial pH 6.5, Incubation temperature $37^{\circ} \mathrm{C}$, Incubation time $48 \mathrm{~h}$.

\begin{tabular}{lc}
\hline $\begin{array}{c}\text { Carbon source } \\
(1 \%)\end{array}$ & $\begin{array}{c}\text { Specific Activity } \\
(\mathrm{U} / \mathrm{mg})\end{array}$ \\
\hline Control* & $1800.6 \pm 18.2$ \\
Mannose & $829.5 \pm 47.1$ \\
Arabinose & $1359.8 \pm 49.5$ \\
Sucrose & $1414.4 \pm 20.9$ \\
Glucose & $1725.1 \pm 18.9$ \\
Galactose & $1244.9 \pm 48.7$ \\
Fructose & $991.6 \pm 57.6$ \\
Lactose & $1338.6 \pm 31.6$ \\
Xylose & $218.6 \pm 18.3$ \\
*Control contains only rice bran and tap water.
\end{tabular}

and inorganic nitrogen source such as ammonium nitrate, sodium nitrate, ammonium chloride and ammonium sulphate to the medium were investigated. As shown in Table 3, in comparison with the control $(1800.6 \pm 18.2 \mathrm{U} / \mathrm{mg})$, there was increase in enzyme yield in the case of the supplementation of ammonium chloride $(2094.9 \pm 53.1 \mathrm{U} / \mathrm{mg})$ which proved to be the best among all the nitrogen sources. It has also been reported that nitrate was inferior to ammonia in $\alpha$-amylase production $[28,41]$.

Various inorganic salts were also studied for their effect on the synthesis and secretion of

Table 3. Effect of nitrogen sources on the production of $\alpha$-amylase by $B$. licheniformis ATCC 12759. Inoculum size $30 \%$ (by volume per mass), volume of medium $100 \mathrm{ml}$, Extraction medium with tap water, Initial pH 6.5, Incubation temperature $37^{\circ} \mathrm{C}$, Incubation time $48 \mathrm{~h}$.

\begin{tabular}{lc}
\hline \multicolumn{1}{c}{ Nitrogen source } & $\begin{array}{c}\text { Specific Activity } \\
(\mathrm{U} / \mathrm{mg})\end{array}$ \\
\hline Control* & $1800.6 \pm 18.2$ \\
Sodium nitrate & $1261.0 \pm 34.9$ \\
Ammonium sulphate & $1888.1 \pm 28.4$ \\
Ammonium nitrate & $1403.8 \pm 19.1$ \\
Ammonium chloride & $2094.9 \pm 53.1$ \\
Beef extract & $1076.0 \pm 8.7$ \\
Tryptone & $1197.6 \pm 19.8$ \\
Peptone & $1115.4 \pm 71.3$ \\
Yeast extract & $1122.0 \pm 37.8$ \\
Urea & $1174.0 \pm 80.0$ \\
Casein & $842.6 \pm 19.7$ \\
$*$ Control contains only rice bran and tap water.
\end{tabular}


Table 4. Effect of metal salt sources on the production of $\alpha$-amylase by $B$. licheniformis ATCC 12759 . Inoculum size $30 \%$ (by volume per mass), volume of medium $100 \mathrm{ml}$, Extraction medium with tap water, Initial pH 6.5, Incubation temperature $37^{\circ} \mathrm{C}$, Incubation time $48 \mathrm{~h}$.

\begin{tabular}{|c|c|}
\hline $\begin{array}{c}\text { Metal salts source } \\
(0.1 \%)\end{array}$ & $\begin{array}{l}\text { Specific Activity } \\
(\mathrm{U} / \mathrm{mg})\end{array}$ \\
\hline Control* & $1800.6 \pm 18.2$ \\
\hline $\mathrm{MgSO}_{4}$ & $1730.6 \pm 28.5$ \\
\hline $\mathrm{ZnSO}_{4}$ & $47.5 \pm 2.3$ \\
\hline $\mathrm{CaCl}_{2}$ & $1763.1 \pm 69.7$ \\
\hline $\mathrm{CuSO}_{4}$ & $54.7 \pm 30.9$ \\
\hline $\mathrm{FeSO}_{4}$ & $1693.0 \pm 9.2$ \\
\hline
\end{tabular}

$\alpha$-amylase production. Comparison with the control $(1800.6 \pm 18.2 \mathrm{U} / \mathrm{mg})$, the production of $\alpha$-amylase by $B$. licheniformis ATCC 12759 was supressed by all metal salt sources (Table 4). The salt requirement for production of this particular enzyme was apparently provided by the nature of rice bran. These are important in terms of the cost of production of enzyme.

\section{CONCLUSION}

Solid waste from rice bran used as the basic nutrient source. Supplementation with carbon and metal salt sources decrased the enzyme production. Certain fermentation parameters involving incubation time, incubation temperature, inoculum level, moisture level, extraction medium, initial $\mathrm{pH}$ and medim volume were studied separately. Maximal amount of $\alpha$-amylase production $(2094.9 \pm 53.1 \mathrm{U} / \mathrm{mg})$ was obtained inoculum level $30 \%$, moisture level $20 \%$, initial pH 6.5 at $37^{\circ} \mathrm{C}$ for $48 \mathrm{~h}$ with supplementation of ammonium cloride.Commercial $\alpha$-amylase production is usually produced by submerged fermentation; however, SSF appear promising due to the natural potential and advantages they offer. Based on the present study, it appears that rice bran, which is inexpensive and readily available agricultural substance, could replace the commercial and more expensive substances in the development of a suitable economic fermentation medium for obtaining high yields of $\alpha$-amylase. However, the present study was entirely a laboratory-scale study, and it has to be further improved for a large-scale SSF.

\section{References}

1. M.Ş. Tanyildizi, V. Selen, D. Özer, Optimization of $\alpha$-Amylase production in solid substrate fermentation, Can. J. Chem. Eng., 87 (2009) 493.

2. O. Kirk, T.V. Borchert, C.C. Fugslang, Industrial enzyme application, Curr. Opin. Biotechnol., 13 (2002) 345.

3. H.R. Palacios, P.B. Schwarz, L.D. D'Appolonia, Effect of $\alpha$-amylases from different sources on the retrogradation and recyclization of concentrated wheat starch gels: relationship to bread staling, J. Agr. Food Chem., 52 (2004) 5978

4. Q.D. Nguyen, J.M. Rezessy-Szabo, M. Claeyssens, I. Stals, A. Hoschke, Purification and characterization of amylolytic enzymes from thermophilic fungus Thermomyces lanuginosus strain ATCC 34626, Enzyme Microb. Technol., 31 (2002) 345

5. G. Rajagopalan, C. Krishnan, $\alpha$-Amylase production from catabolite derepressed Bacillus subtilis $\mathrm{KCC1O} 3$ utilizing sugarcane bagasse hydrolysate, Bioresource Technol., 99 (2008) 3044.

6. A. Burhan, U. Nisa, C. Gokhan, C. Omer, A. Ashabil, G. Osman, Enzymatic properties of a novel thermostable, thermophilic, alkaline and chelator resistant amylase from an alkaliphilic Bacillus sp. isolate ANT-6, Process Biochem., 38 (2003) 1397.

7. S. Sivaramakrishnan, D. Gangadharan, K.M. Nampoothiri, C.R. Soccol, A. Pandey, $\alpha$-Amylases from microbial sources-an overview on recent developments, Food Technol. Biotechnol., 44 (2006) 173.

8. I. Haq, H. Ashraf, J. Iqbal, M.A. Qadeer, Production of alpha amylase by Bacillus licheniformis Using an economical medium, Bioresource Technol., 87 (2003) 57.

9. P. Ellaiah, K. Adinarayana, Y. Bhavani, P. Padmaja, B. Srinivasulu, Optimization of process parameters for glucoamylase production under solid state fermentation by a newly isolated Aspergilus species, Process Biochem., 38 (2002) 615.

10. H. Anto, U. Trivedi, K. Patel, Alpha amylase production by Bacillus cereus MTCC 1305 using solid-state fermentation, Food Technol. Biotechnol., 44 (2006) 241.

11. M.R. Swain, R.C. Ray, Alph-amylase production by Bacillus subtilis CM3 in solid state fermentation using cassava fibrous residue, J. Basic Microb., 47 (2007) 417

12. G.V. Reddy, P.R. Babu, P. Komariah, K.R.R.M. Roy, I.L, Kothari, Utilization of banana waste for the production of lignolytic and cellulolytic enzymes by solid substrate fermentation using two Pleurotus Species ( $P$. ostratus and $P$. sajor-caju), Process Biochem., 38 (2003) 1457.

13. Z. Baysal, F. Uyar, C. Aytekin, Solid state fermentation for production of $\alpha$-amylase by a thermotolerant Bacillus subtilis from hot-spring water, Process Biochem., 38 (2003) 1665.

14. A. Pandey, solid-state fermentation, Biochem. Eng. J., 13 (2003) 81.

15. A. Pandey, P. Selvakumar, C.R. Soccol, P. Nigam, Solid state fermentation for the production of industrial enzymes, Curr. Sci., 77 (1999) 149. 
16. P. Viswanathan, N.R. Surlikar, production of $\alpha$-amylase with Aspergillus flavus on Amaranthus grains by solidstate fermentation, J. Basic Microbiol., 41 (2001) 57.

17. P. Bernfeld, Amylases, $\alpha$ and $\beta$. In methods in enzymology, Academic Press, 1 (1955) 149.

18. O.H. Lowry, N.J. Rosebrough, A.L. Farr, R.J. Randall, Protein measurement with the folin-phenol reagents, J. Biol. Chem., 48 (1951) 17.

19. A. Kunamneni, K. Permaul, S. Singh, Amylase production in solid state fermentation by the thermophilic fungus Thermomyces lanuginosus, J. Biosci. Bioeng., 100 (2005) 168.

20. I. Akpan, F.A. Adelaja, Production and stabilization of amylase preparations from rice bran solid medium, World J. Microb. Biot., 20 (2004) 47.

21. V.H. Mulimani, G.N.P. Ramalingam, $\alpha$-Amylase production by solid-state fermentation: a new practical approach to biotechnology courses, Biochem. Educ., 28, (2000) 161.

22. H. Singh, S.K. Soni, Production of starch-gel digesting amyloglucosidase by Aspergillus oryzae HS-3 in solid state fermentation, Process Biochem., 37 (2001) 453.

23. H.K. Sodhi, K. Sharma, J.K. Gupta, S.K. Soni, Production of a thermostable $\alpha$-amylase from bacillus sp. ps-7 by solid- state fermentation and its synergistic use in the hydrolysis of malt starch for alcohol production, Process Biochem., 40 (2005) 525.

24. K.R. Babu, T. Satyanarayana, $\alpha$-Amylase production by thermophilic Bacillus coagulans in solid state fermentation, Process Biochem., 30 (1995) 305.

25. M.V. Ramesh, B.K. Lonsane, Solid-state fermentation for production of alpha amylase by Bacillus megaterium 16M, Biotechnol Lett., 9 (1987) 323.

26. B. Balkan, F. Ertan, Production and properties of $\alpha$-amylase from Pencillium chrysogenum and its applications in starch hydrolysis, Prep. Biochem. Biotechnol., 35 (2005) 169.

27. A. Pandey, Improvement in solid-state fermentation for glucoamylase production, Biological Wastes., 34 (1990) 11.

28. S. Ramachandran, A.K. Patel, K.M. Nampoothiri, F. Francis, V. Nagy, G. Szakacs, A. Pandey, Coconut oil cake-a potential raw material for the production of $\alpha$-amylase, Bioresource Technol., 93 (2004) 169.

29. G. Rajagopolan, C. Krishnan, Optimization of medium and process parameters for a constitutive $\alpha$-amylase production from a catabolite derepressed Bacillus subtilis KCC103, J. Chem. Technol., 83 (2008) 654.

30. N. Akcan, High level production of extracellular $\alpha$-amylase from Bacillus licheniformis ATCC 12759 in submerged fermentation, Rom. Biotech. Lett., 16 (2011) 6833.
31. D. Gangadharan, S. Sivaramakrishnan, K.M. Nampoothiri, A. Pandey, Solid culturing of Bacillus amyloliquefaciens for alpha amylase production, Food Technol. Biotechnol., 44 (2006) 269.

32. A.K. Mukherjee, M. Borah, S.K. Rai, To study the influence of different components of fermentable substrates on induction of extracellular $\alpha$-amylase synthesis by Bacillus subtilis DM-03 in Solidstate fermentation and exploration of feasibility for inclusion of $\alpha$-amylase in laundry detergent formulations, Biochem. Eng. J., 43 (2009) 149.

33. S.A. Ahmed, Optimization of production and extraction parameters of Bacillus megaterium levansucrase using solid-state fermentation, J. Appl. Sci. Res., 4 (2008) 1199.

34. R. Gupta, P. Gigras, H. Mohapatra, V.K. Goswami, B. Chauhan, Microbial $\alpha$-amylases: a biotechnological perspective, Process Biochem., 38 (2003) 1599.

35. D.A. Mitchell, N. Krieger, D.M. Stuart, A. Pandey, New developments in solid-state fermentation II. rationa approaches to the design, operation and scale-up of bioreactors, Process Biochem., 35 (2000) 1211.

36. S.M. Kotwal, M.M. Gote, S.R. Sainkar, M.I. Khan, J.M. Khire, Production of $\alpha$-galactosidase by thermophilic fungus Humicola sp. in solid state fermentation and its application in soyamilk hydrolysis, Process Biochem., 33 (1998) 337.

37. K. Das, R. Doley, A.K. Mukherjee, Purification and biochemical characterization of a thermostable, alkaliphilic, extracellular $\alpha$-amylase from Bacillus subtilis DM-03, isolated from the traditional fermented food of India, J. Biotechnol. Appl. Biochem., 40 (2004) 291.

38. J.G.N. Amissah, W.O. Ellis, I. Oduro, J.T. Manful, Nutrient composition of bran from new rice varieties under study in Ghana, Food Control., 14 (2003) 21.

39. M.V. Ramesh, B.K. Lonsane, Ability of a solid state fermentation technique to significantly minimize catabolite repression of alpha-amylase production by Bacillus lichneformis M27, Appl. Microbiol. Biot., 35 (1991) 591.

40. H. Sun, X. Ge, W. Zhang, Production of a novel rawstarch-digesting glucoamylase by Penicillium sp. $\mathrm{X}-1$ under solid state fermentation and its use in direct hydrolysis of raw starch, World J. Microbiol. Biotechnol., 23 (2007) 603.

41. H. Pedersen, J. Nielsen, The influence of nitrogen sources on the alpha amylase productivity of aspergillus oryzae in continuous cultures, Appl. Microbiol. Biotechnol., 53 (2000) 278. 